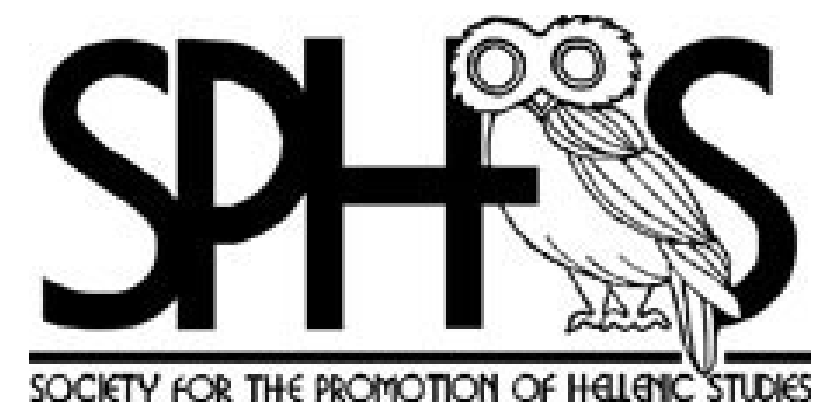

The Modern Carnival in Thrace and the Cult of Dionysus Author(s): R. M. Dawkins

Source: The Journal of Hellenic Studies, Vol. 26 (1906), pp. 191-206

Published by: The Society for the Promotion of Hellenic Studies

Stable URL: http://www.jstor.org/stable/624371

Accessed: 16/01/2015 05:34

Your use of the JSTOR archive indicates your acceptance of the Terms \& Conditions of Use, available at

http://www.jstor.org/page/info/about/policies/terms.jsp

JSTOR is a not-for-profit service that helps scholars, researchers, and students discover, use, and build upon a wide range of content in a trusted digital archive. We use information technology and tools to increase productivity and facilitate new forms of scholarship. For more information about JSTOR, please contact support@jstor.org.

The Society for the Promotion of Hellenic Studies is collaborating with JSTOR to digitize, preserve and extend access to The Journal of Hellenic Studies. 


\section{THE MODERN CARNIVAL IN THRACE AND THE CULT OF DIONYSUS.}

MY attention was called recently to an account by G. M. Vizyenos ${ }^{1}$ of a Carnival festival celebrated in the district about Viza (ancient $\mathbf{B} \iota \zeta^{\prime} \eta$ ) in Thrace so remarkable that it seemed worth while to verify the author's account by a personal visit. This I was able to do at the Carnival of $\mathbf{1 9 0 6 ,}$ and the account below has been drawn up from my notes, supplemented by this article, from which I quote everything of value.

Of the writer's good faith there is no doubt, and of almost all the points he mentions I had ocular confirmation. He was a native, not of Haghios Gheorghios, the village whose festival he describes, but of Viza itself, the chief place in the district, lying some two hours to the west. He left his uative place while still a boy, and died at Athens in 1896, aged forty-two. The middle part of his life he spent in Germany, and he does not seem ever to have returned to Thrace. ${ }^{2}$ His account is therefore probably a description of the festival as it was in his youth some forty years ago, when modern conditions had affected the district even less than at present. He calls it

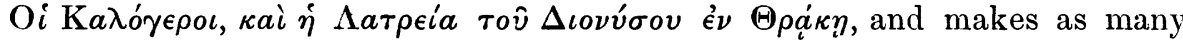
classical comparisons as possible. All these I have omitted, and drawn upon him only for matters of fact.

The town of Viza lies on and around the Acropolis of the ancient city, and some eight hours by road north of the station of Tcherkesskeui on the railway between Constantinople and Adrianople, and nine hours from Midheia (Salmydessus) on the Black Sea. It is built on the last slopes of the low hills that shut off the view of the sea, where these rise from the wide plain of Thrace. This is watered by the tributary streams of the Tearus, said to be exactly the thirty-eight reckoned by Herodotus, and is studded with conspicuous tumuli, of the same shape but generally rather larger than those on the English downs. They are said to contain the bones of men and horses, and the iron and bronze fittings of a chariot have been found in

1 In the first and only number published of

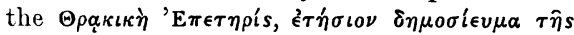

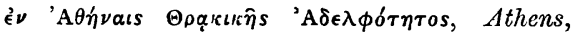
1897, to which my attention was first called by

H.S.-VOL. XXVI.
Mr. F. W. Hasluck.

2 Details of his life are given in a book on

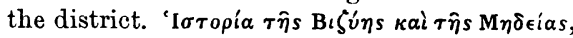

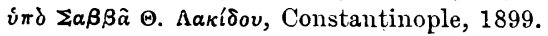


such a tumulus, and are now in the Museum at Sofia. ${ }^{3}$ In date they hardly seem to be earlier than the beginning of our era, and many of them are a good deal later. A fair number of inscriptions are preserved in the modern town, four of which record names of kings and dynasts of Thrace, whose palace was at Viza. ${ }^{4}$ The most conspicuous remains of this period are the fine walls (Fig. 1) that still stand on the western and southern sides of the Acropolis, now the Turkish quarter, and testify to its former strength. A gate, flanked by a pair of towers and surmounted by a quadriga, is represented on two coins of Hadrian. A Roman altar, a base sculptured with cupids supporting garlands and heads of animals, and two early

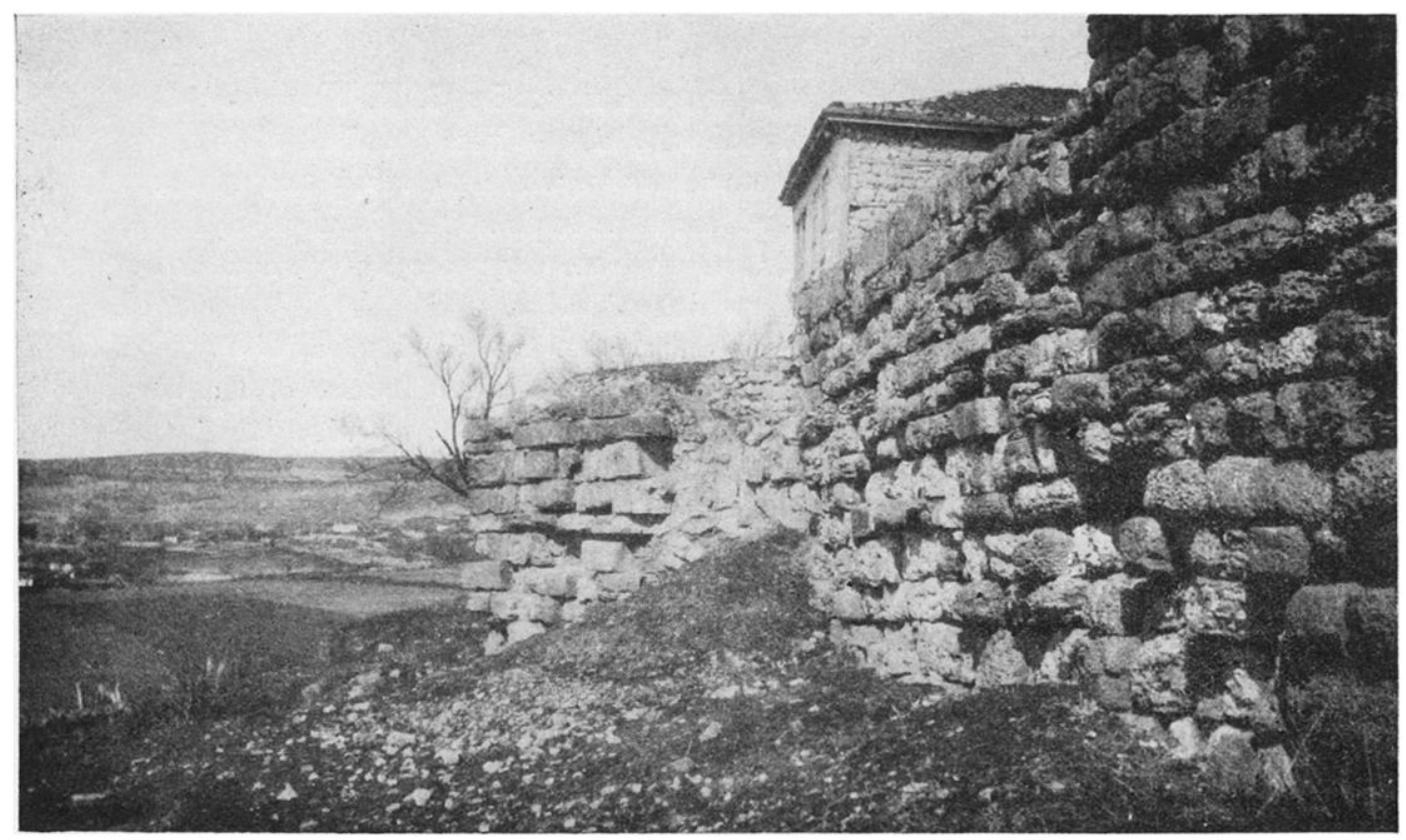

Fig. 1.-The Walls of Viza.

Christian gravestones carry us further down, and the imposing church of Haghia Sophia (Fig. 2), now a mosque; shews that the place was of some importance in Byzantine times. Not far from Haghia Sophia is a conspicuous domed Byzantine building, also formerly a church, and within the Acropolis area (Kalch) are other less important ancient and Byzantine remains, the most interesting of which are numerous blocks which once formed the seats of a theatre, and a large vaulted structure of the Byzantine age, to which also belong several fine military towers. Viza is now a town of 3,500 inhabitants, of whom 2,500 are Greeks and 1,000 Turks, and the seat of a bishop and a Kaimakam.

3 B.C.H. xxv. 1901, pp. 156-220.

4 To be published in $B . S . A$. xii. 
In all the knot of Christian villages, of which Viza is the centre, the

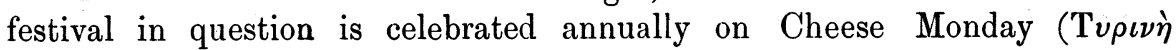
$\left.\Delta \epsilon v \tau \tau^{\prime} \rho a\right)$. This day begins the last week of Carnival, which culminates on

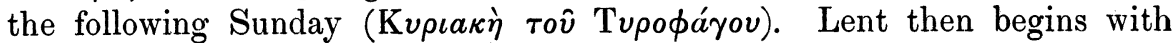

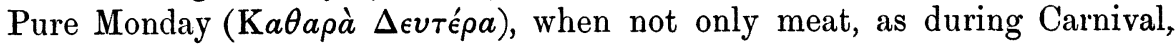
but also all kinds of animal food except bloodless molluscs are forbidden.

The masquerade of this day was, even when Vizyenos saw it, no longer kept up in its fulness at Viza itself, but only in the neighbouring villages, of which he takes Haghios Gheorghios (Turkish, Evrenlu) as an example. At this village $\mathrm{I}$ also spent Cheese Monday, and during my stay of a week in

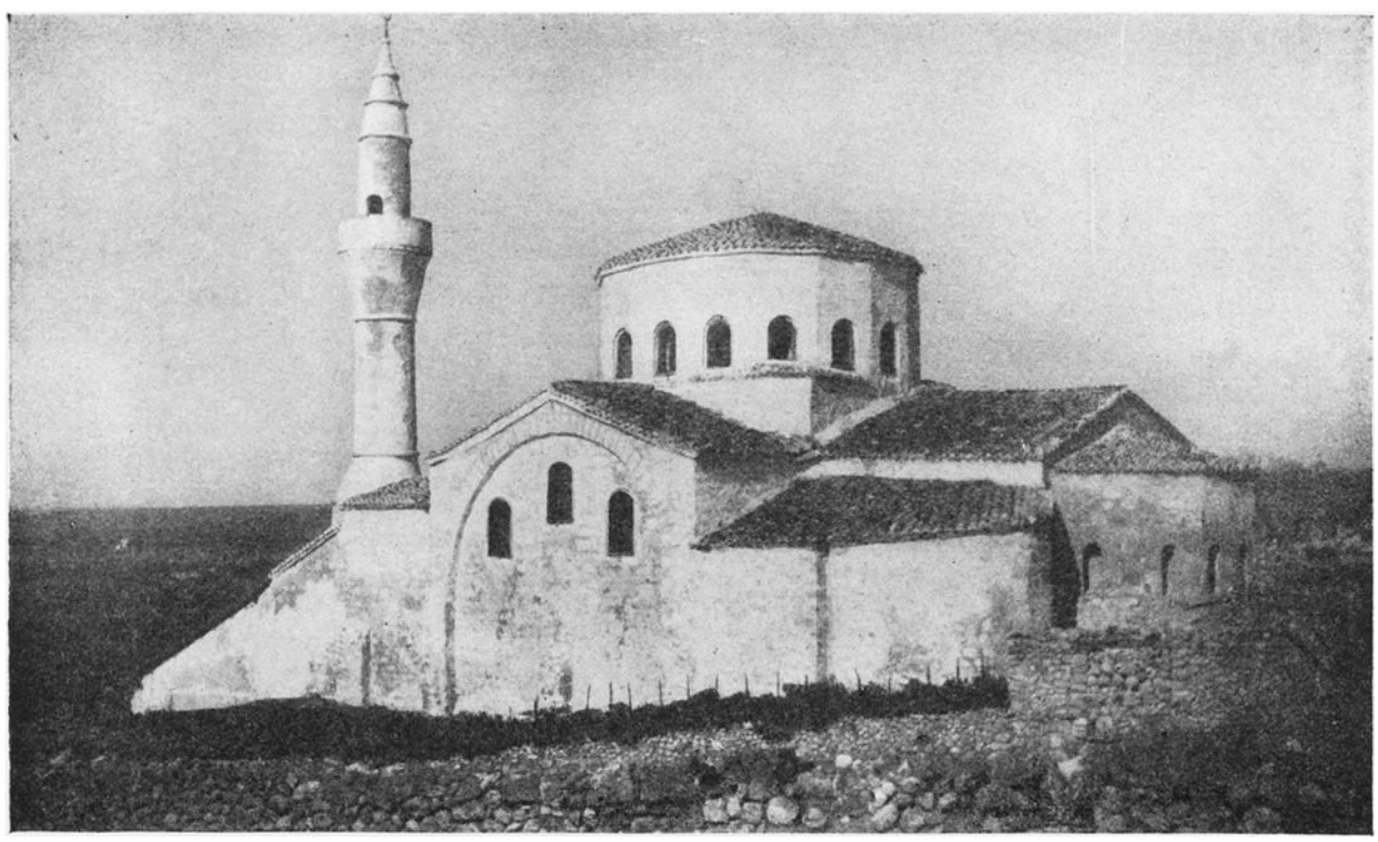

Fig. 2.-Church of Haghia Sophia, Viza, from South-East.

the district was able to supplement my notes by enquiries about the observances in other places.

The list of masqueraders is as follows :-

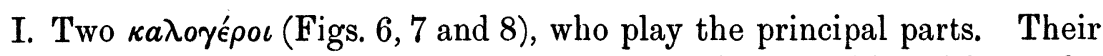
disguise consists of a headdress formed of an entire goatskin without the horns, stuffed out with hay so as to rise like a great shako at least a foot or eighteen inches above the head, and adorned at the top with a piece of red ribbon. The skin falls over the face and neck, forming thus a mask, with holes cut for the eyes and mouth. Round the waist three or four sheep-bells are tied, and their hands are blackened. Their shoulders are monstrously 
padded with hay to protect them from blows, which, from Vizyenos' account, they used to receive more freely than at present. He adds that the headdress may be made of the skin of a fox or wolf, and that fawnskins were worn on the shoulders, and upon the legs goatskins. The essential and

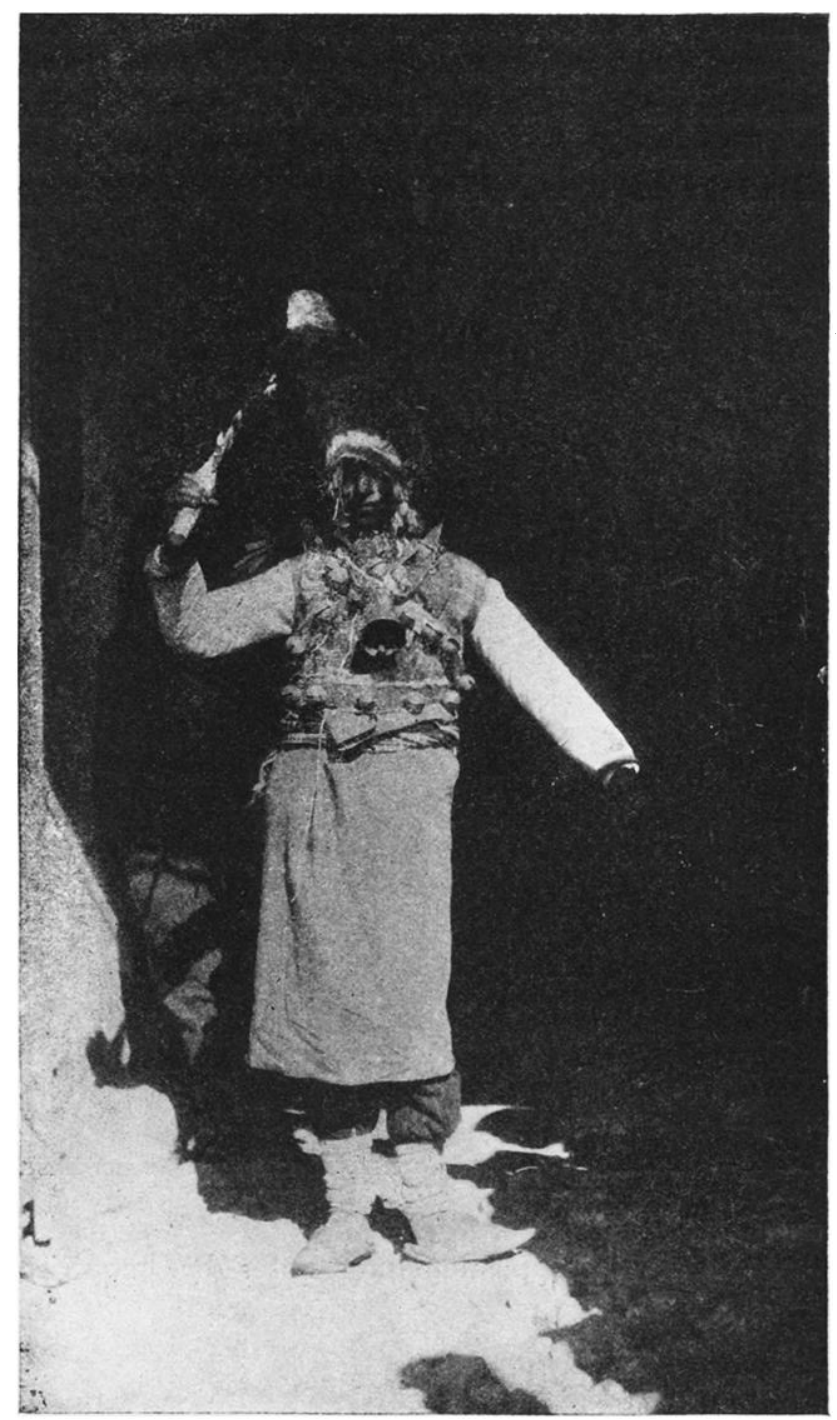

Fig. 3.-A Kalogheros at Viza.

indispensable elements, he says, are the mask and bells. It would seem from this that the resemblance of the actor to an animal was formerly a good deal more marked than at present. A little boy whom I saw on the Tuesday at Viza acting as kalogheros (Fig. 3), the only part there surviving, 
wore a tall conical fur cap and bells at his waist. He had no mask, but his face as well as his hands was blackened. In one of the villages the kalogheroi do not wear skins at all on their heads, but beehives. One of the kalogheroi at Haghios Gheorghios carries a wooden phallus (Fig. 4c), and the other a mock bow (Fig. $4 b$ ).

This bow ( $\delta o \xi a ́ \rho \iota)$ is in general appearance rather like a crossbow, but is made only to scatter ashes or powder, which are placed in a cow's horn fastened to the end of the moveable piece that takes the place of the arrow. Vizyenos adds that the carrier of the bow is the leader of the two, and the other his servant and follower. I could observe no difference in their importance, though I shall bring reasons below for believing that his

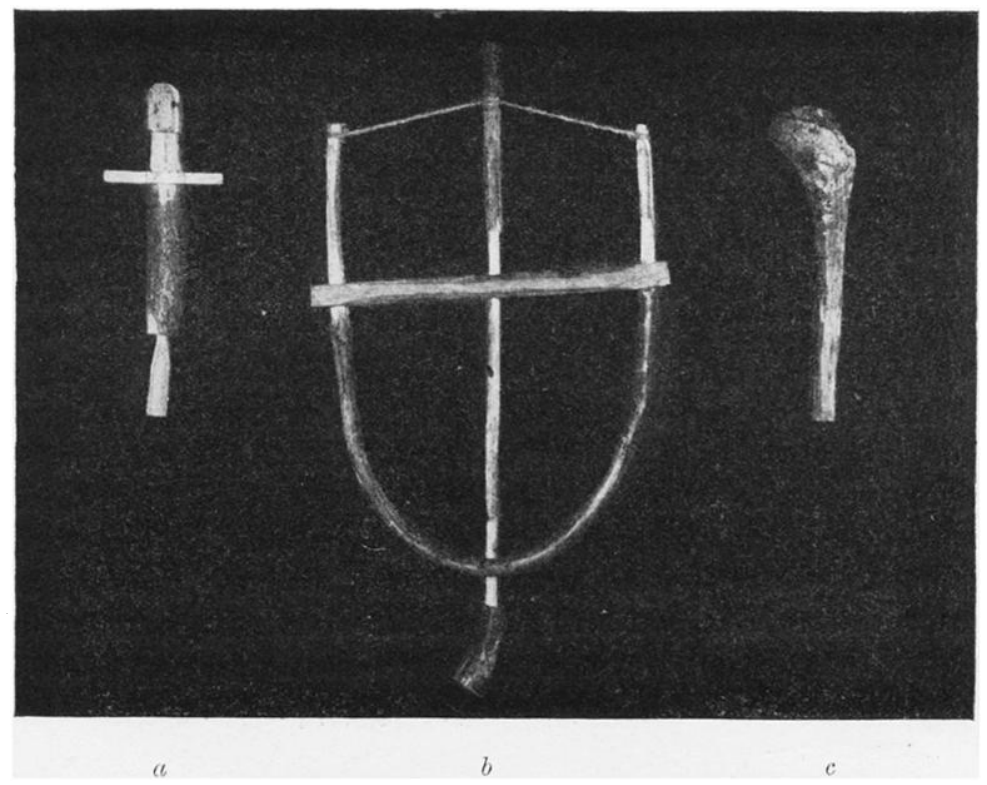

Fig. 4. - $a$ Puppet. $b$ Bow. $c$ Phallus.

statement that one plays only a secondary part is correct, and represents a less corrupt version of the play. In the drama with which the day closes, it is the carrier of the bow who shoots the other, and in this point Vizyenos agrees with my observations; as, however, he says that the second actor is the slayer, he seems to be in self-contradictory error in assigning the bow to the leader.

II. Two boys dressed as girls (Kopitoıa), called also in some other villages, according to Vizyenos, $\nu$ ú $\phi \in s$, brides (Figs. 7 and 8). These wear a white skirt and apron, a peasant woman's bodice open in front, and kerchiefs binding the chin and brow. A third kerchief hangs down behind, and from beneath it escapes a corded black fringe like finely plaited hair. ${ }^{5}$ They

5 The fringe of a kind of woman's scarf is used for this purpose. 
check any liberties with knotted handkerchiefs weighted with a few bullets.

It is to be noted that the laalogheroi at Haghios Gheorghios must be married men, and the lioritsic unmarried. Vizyenos tells us also that these four actors are chosen for periods of four years and that during this time a lioritsi may be betrothed, but must remain unmarried, a father being able to refuse to allow his son to take this part on the ground that he is thinking of

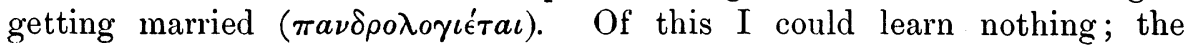
kalogheroi for 1906 had acted for more than four years, and the period seems quite unsettled. But the rule about marriage remains clearly fixed.

III. Next comes a third female character, the Babo, a word in general local use meaning an old woman. This character was not represented in the play I saw, but her place was taken by another female personage described

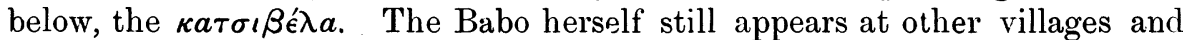
until quite recently was seen at Viza, where she has now been forbidden by the authorities. She is described by Vizyenos as a man dressed as an old woman carrying on her arm a basket containing ' some absurd object or piece of wood swaddled in rags,' which she treats as a baby. Of this child she is

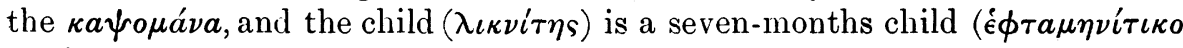
$\pi a \iota \delta i)$ born out of lawful wedlock of a father whose name she does not know: This account there is no reason to doubt. The Babo's child, I was told at Viza, was always regarded as bastard. Kaqouáva I understood to mean 'nurse' or 'foster-mother,' but Vizyenos says that the Babo regards the child as her own, and kindred words ${ }^{6}$ make it almost certain that the real meaning is ' unmarried mother, mother of an illegitimate child.' 7 The word $\lambda i \kappa \nu \iota$ survives in the district, especially at Sammakóv and Mídheia, meaning a cradle, made as usual of wood and shaped like a trough. Further evidence for it at Viza is supplied by its use in a local version of the song of the 'Bridge

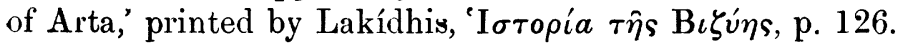

The lines are :-

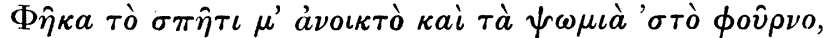

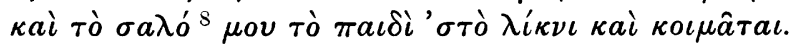

I have left my house open, and the bread in the oven, and my innocent child in the cradle sleeping, spoken by the mother who must leave her home to be killed and buried beneath the bridge that it may be firmly founded. $\Lambda \iota \kappa \nu$ i $\omega$ means to rock the cradle, but $\lambda \iota \kappa \nu i \tau \eta s$ was explained to me as meaning, not; the baby, as Vizyenos gives it, but the person who rocks the cradle. For this latter meaning the word should, however, be oxytone, and it is likely that my informant read the word wrongly, and that Vizyenos is making no error

${ }^{6}$ Capseḍda · Miidchen, from Bova (G. Meyer,

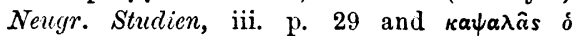

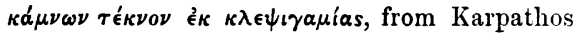

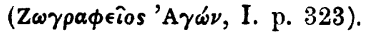

7 The meanings 'nurse' and 'unmarried mother, mother who is not a wife' are not so far apart but that the word may bear both senses.

8 Lakidhis explains $\sigma \alpha \lambda o ́$ as meaning $\mu \omega \rho o ́$, 'innocent.' 
in recording $\lambda \iota \kappa \nu i \tau \eta$ s as a genuine local word for a baby in a cradle. In any case the use of derivatives of $\lambda i \kappa \nu o \nu$ in the sense of cradle is certain. It is only at this festival that a basket is used as a cradle, and even then not invariably. The Babo at Viza used to carry a piece of tile for this purpose. $\Lambda \iota \kappa \nu ' \zeta \omega$ has also its usual meaning of winnowing, and $\lambda \iota \kappa \nu a ́ \rho \iota$ means a winnowing fork. Nowhere else in Greece have I found any evidence for these words used of baskets or cradles. ${ }^{9}$

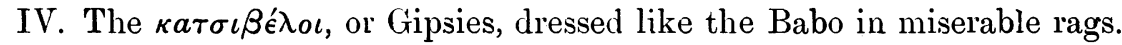
Of these Vizyenos says there are three or four, all apparently male, though elsewhere he incidentally mentions the female $\kappa a \tau \sigma \iota \beta \hat{\lambda} \lambda a$. I saw two only,

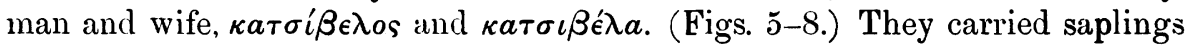
some ten or twelve feet long, and their faces and hands were blackened. The lictsivelos had no other disguise, but his wife wore a woman's coat and on the head a kerchief and a little false hair. When the actors were dressing I

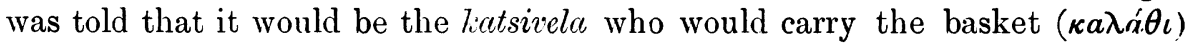
and the baby, and on my asking where the basket was, he ran off and got a rough basket with a little wool in it to make a bed, and, breaking off a piece of stick, put it into the basket and nursed it, and played with it as if with a baby. When the actors began to perambulate the village, this was quickly dropped, and the carrying of the baby seems just dying out at Haghios Gheorghios, where the katsivela has partly taken the place of the Babo, and, as being also an old woman, occasionally her name as well. The doll shown in Fig. $4 a$ was made for me at Viza to be exactly like the figure that the Babo there used to carry.

V. The last characters are the Policemen. These are two or three young men carrying swords and whips, with embroidered kerchiefs tied round their fezzes. One of them carried also a length of chain, for making

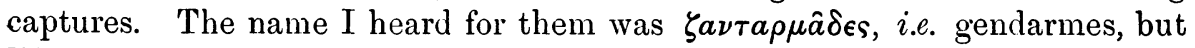
Vizyenos calls them $\zeta a \pi \tau \iota \epsilon \in \epsilon \varsigma, \kappa o v \rho o v \tau \zeta \bar{\eta} \delta \epsilon \varsigma$, or $\phi u ́ \lambda a \kappa \epsilon \varsigma$. géda).

Lastly a man accompanies the others, playing on a bagpipe ( $\gamma \kappa \in$ éva

The masqueraders get ready in the morning and spend the day in visiting each house in the village, receiving everywhere bread, eggs, or money. The two katogheroi lead the crowd, knocking loudly at the duors with the bow and phallus, and with the lioritsia generally dance a little hand-in-hand, before the housewife brings out her contribution. They are followed by the katsivelos and katsivela, who are especially privileged to scare fowls and rob nests. In general anything lying about may be seized as a pledge to be redeemed, and the lioritsic especially carry off babies with this object, and occasionally capture a man with their handkerchiefs. A recurring feature is

\footnotetext{
9 I am uncertain whether the modern pronunciation does not as commonly demand $\chi$ in these words instead of $\kappa$. It certainly does in

the neighbouring district of Saránda Ekklisies

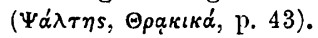


an obscene pantomime between the katsivelos and his wife on the straw-heaps in front of the houses.

By the afternoon no house was left unvisited, and everybody, men and women, gathered round the open space in front of the church at the top of the village. Here the drama proper is enacted. It began with a hand-inhand dance of all the characters, the zandarmádlues brandishing their drawn swords. The lialogheroi then withdrew, leaving the field to the gipsy smiths, the katsivelos and his wife. These sat on the ground facing each other, and the katsivelos pounded on the ground with a stone, whilst the liatsivela lifted her skirts up and down. This is understood to be a pantomimic representation of the forging of a ploughshare, the man hammering like a blacksmith, whilst the fanning with the skirts represents the action of a pair of bellows,

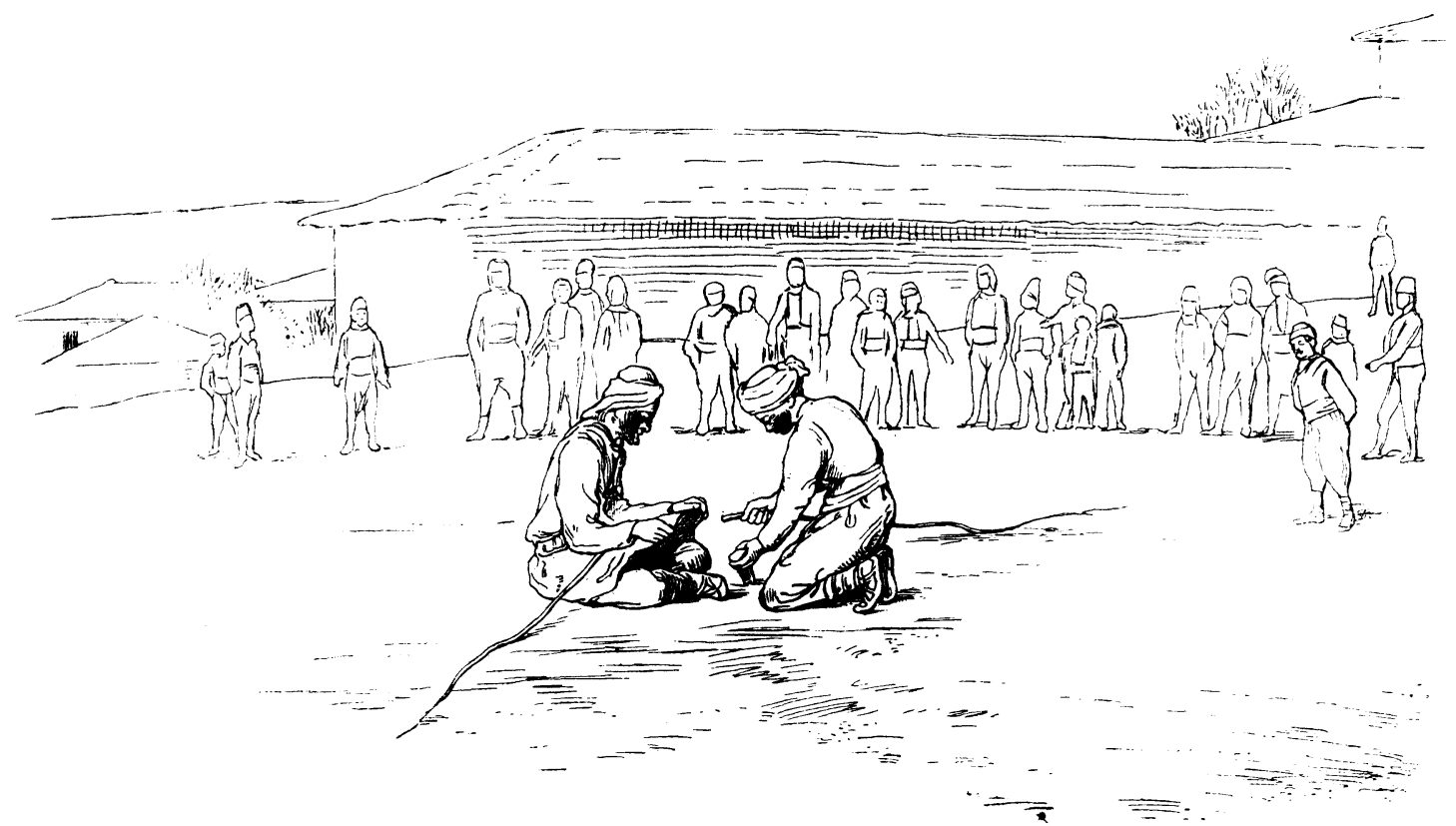

Fig. 5. -The Katsivelor makisg the Plolghshate.

and is represented in Fig. 5, in which the katsivela is seen pretending to work the bellows on the left, and her husband opposite. At this point, according to Vizyenos, the Babo's child begins to grow up, and she finds that $\tau \grave{o} \mu \omega \rho \grave{o}$

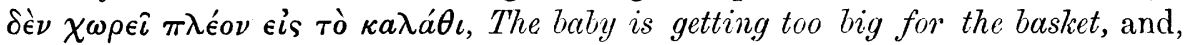
together with a huge appetite for meat and drink, he begins to demand a wife. This, according to Vizyenos, is followed by the chief kalogheros pursuing one of the koritsic and the celebration between them of a mock marriage, parodying the Greek rite of crowning the bride and bridegroom. The part of

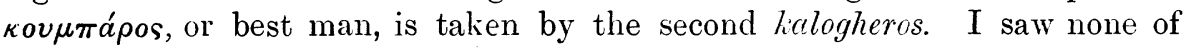
this, but it was understood that the koritsia were the wives of the kalogheroi, and $I$ was informed that in the adjacent village of Dzaklé such a mock 
marriage is performed with old baskets instead of crowns and the burning of dirt for incense. But both there and also at Haghios Gheorghios both kalogheroi are married, otherwise, indeed, the presence of the second koritsi, except perhaps as a bridesmaid, is hard to explain. But the account of Vizyenos, as the comparison made below with the Skyros and Kosti festivals indicates, represents a clearly more primitive tradition.

Presently the first kalogheros was seen sauntering about, or standing the phallus upright on the ground and sitting upon it. Meanwhile his comrade was stalking him from behind and at last shot him with the bow, at which he fell down on his face as if dead. After making sure that he was really dead, the slayer traced a line round the body, as if to mark the size of the grave needed. He then pretended to flay $\left(\gamma \delta \delta^{\prime} \rho \nu \omega\right)$ the dead body, using for

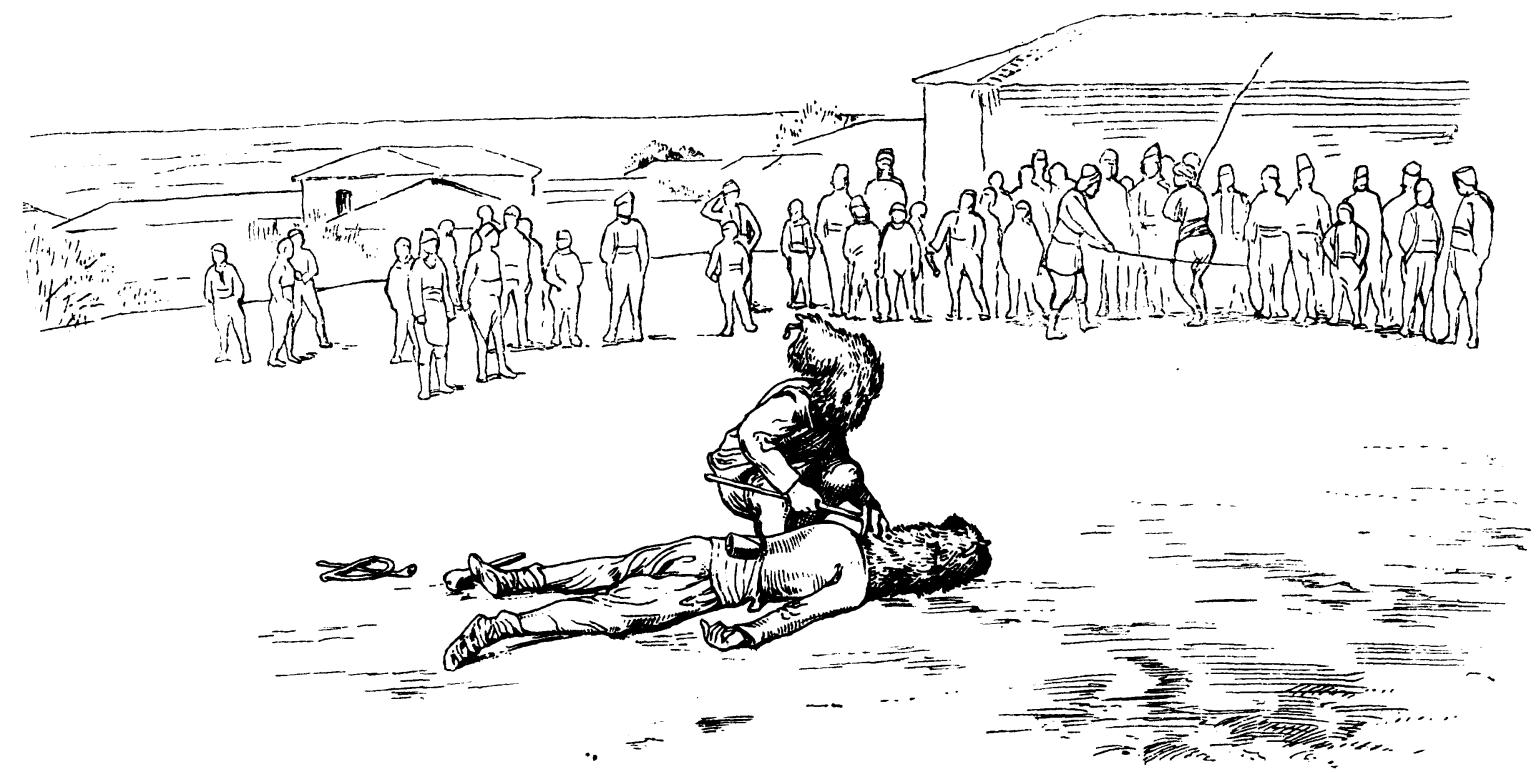

Fig. 6.-The Flaying of the dead Kalogheros.

the purpose a kind of pick (chelounji) ${ }^{10}$ and also making a show of sharpening a stick, as if it had been a knife. A wooden knife is sometimes used. Of this flaying Vizyenos says nothing. It is represented in Fig. 6, in which the bow and phallus are lying on the ground on the left, and in the background on the right the katsivelos and his wife appear with their long wands. The padded back of the dead masker should be noted. Whilst the kalogheros is thus lying dead, one of the koritsia in the character of his wife laments for him with loud cries, throwing herself across the prostrate body, as is shewn in Fig. 7. The katsivelos and his wife also form part of the group. In this lamentation Vizyenos says that the slayer and the rest of the actors join,

${ }^{10}$ A grecized form of the Turkish kulunk. 
making a regular parody of a Christian funeral, burning dung as incense and pretending to sing the service, and finally lifting up the corpse to carry it away. After the lamentation of the loritsi the dead man suddenly came alive again and got up, thus ending this part of the play.

Then the katsivelos and his wife repeated the forging of the ploughshare, this time hammering on a real share. At some time in the play the katsivelos usually rides on a donkey, but this was omitted owing to the bad weather. Snow had been falling all day, and perhaps the extreme cold tended to curtail the details of the performance. Vizyenos also mentions some rough play with a donkey, but puts it down to the kalogheroi. At about this point all the implements used were thrown high into the air with cries,

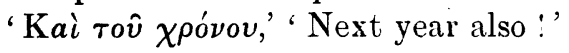

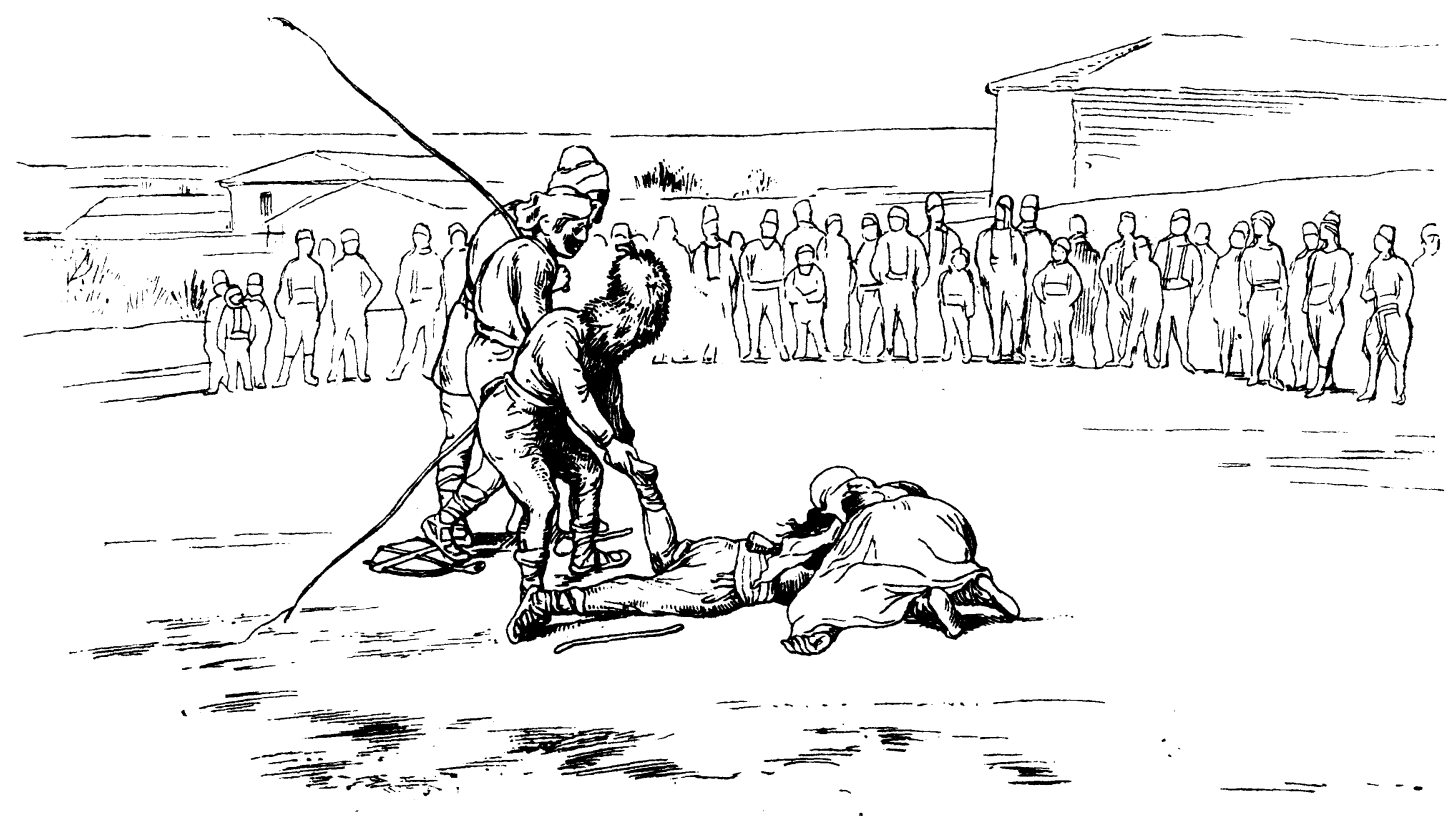

Fig. 7.-The Dead Kaloghenos Lamented by his Bride.

The share being supposed to be finished, a real plough was brought forward, and the mockery seemed to cease. Instead of oxen, the koritsia were yoked and dragged it round the village square twice contrary to the way of the sun. One of the knlogheroi was at the tail of the plough and the other guided it in front, whilst a man walked behind scattering seed from a basket. This is shewn in Fig. 8, with the liatsivelos and his wife walking in front. The man with the seed was not included in the photograph from which the drawing was made. The latsivelos and lictsivela were then yoked and made a third circuit, the lialogheroi still guiding. Vizyenos says that the kalogheroi draw the plough, in which he seems to be thinking of the practice at Viza, where until recently this custom was still kept up and it was so 
drawn. But at Haghios Gheorghios it seems always to have been drawn by the koritsia, for a native now resident at Viza, who had not seen the festival for ten years or more, corrected Vizyenos' report on this point. The cries

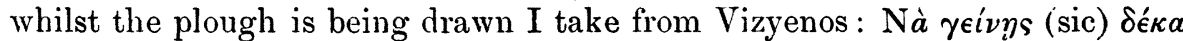

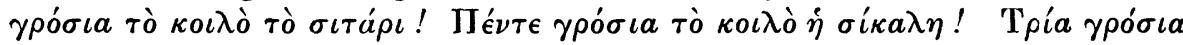

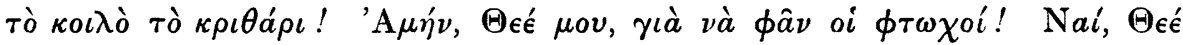

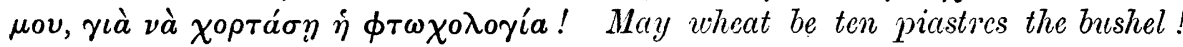
Rye five piastres the bushel! Burley three piastres the bushel! Amen, O God, that the poor may eat! Yea, O God, that poor foll be filled!

This was the end of the play, and the evening was spent in feasting on the presents collected during the day.

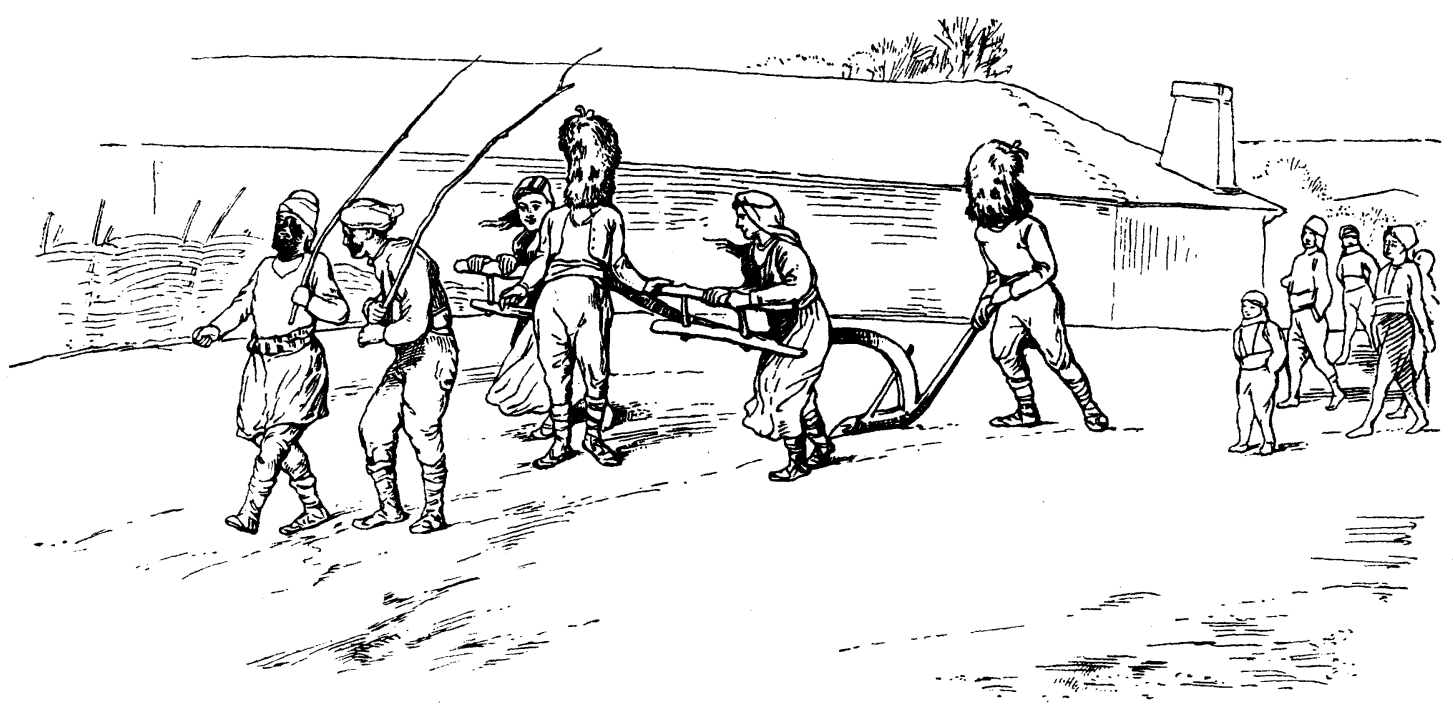

Fig. 8. -The Plovghing.

Such is the festival celebrated every spring by the Greek community in these villages. Before examining it more closely it will be convenient to notice some other similar customs.

A kindred festival is observed on the same day at Kostí, in the very north of Thrace, near the Black Sea and the Roumanian frontier. I take an account of it from a pamphlet published at Constantinople. ${ }^{11}$ A man,

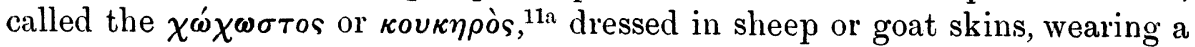
mask and with bells round his neck, and in his hand a broom of the kind used for sweeping out ovens, goes round collecting food and presents. $\mathrm{He}$ is addressed as king and escorted with music. With him is a boy carrying a wooden bottle and a cup, who gives wine to each householder, receiving in return a gift. They are accompanied by boys dressed as girls. The king

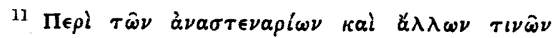

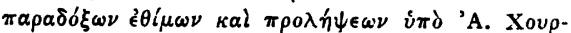

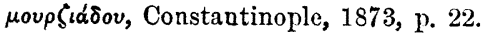

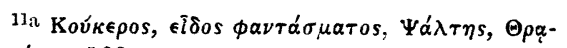
кเка́, p. 183.
} 
then mounts a two-wheeled cart and is drawn to the church. Here two bands are formed of married and unmarried men respectively, and each tries to make the king throw upon themselves the seed which he holds in his hands. This he finally casts on the ground in front of the church. He is then thrown into the river, stripped of his skin clothes (ó $\boldsymbol{o}^{\prime} \gamma \nu \mu \nu \boldsymbol{s}$ ), and then resumes his usual dress. The throwing into the river is clearly a rain charm.

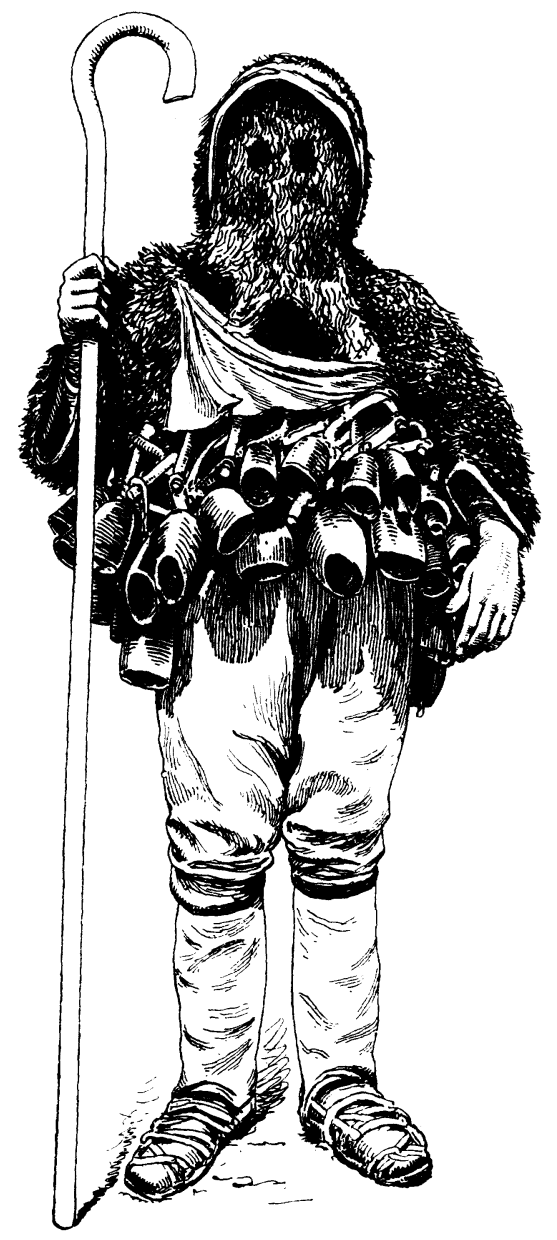

Fig. 9.-Masquerader from Skyros. (From B.S.A. xi.)

The custom at the Skyros Carnival described by Mr. Lawson, ${ }^{12}$ and again by the present writer, ${ }^{13}$ is closely allied, though much less of it is left. There is no drama, but only the going about the town of sets of three masqueraders, the Old Man ( $\gamma$ épos) (Fig. 9) ${ }^{14}$ with bells and skin mask and,

12 B.S.A. vi. p. 125

1:3 B.S.A. xi. 1. 72.
14 Reproduced from B.S.A. xi. 1. 73 , Fig. 1. 
according to Mr. Lawson, with skin cape also, who answers to the leading

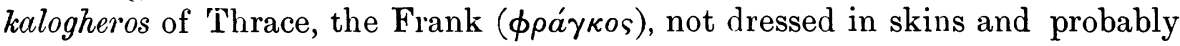
corresponding to the second kalogheros, and the koritsi, a boy dressed as a girl. The statement of Vizyenos that only the first lialogheros is married and the single skinclad 'king' at Kostí, and the single Old Man with his bride at Skyros, make it likely that this represents a clearer tradition, and that the marriage of the second kalogheros is a comparative innovation. A passage in Fiedler, who observed the custom, shows that the phallic element was formerly present at Skyros also. He says: 'Einige kamen als Frauen verkleidet und Maenner hatten einen Flaschenkuerbiss mit langem Halse, von welchem sie einen sehr obscoenen Gebrauch machten zum allgemeinen Gelaechter der Zuschauer.' ${ }^{15}$

These observances fall into line with the numerous spring festivals of the spirit of vegetation, of which Dr. Frazer has written at length in the Golden Bough. The king and the rain charm by wetting at Kostí, and the marriage, death, and resurrection at Viza, are unmistakable marks of this almost worldwide group of customs. The prayers during the ploughing ceremony for an abundant harvest show that this is, or was, regarded as a magic rite to make the crops grow, as in the cases collected by Dr. Frazer, ${ }^{16}$ where it is especially the work of women. The dancing and leaping of the principal actors, so conspicuous at Skyros, fall, like the jumping of the Salii at Rome, under the same head, ${ }^{17}$ and the protective padding of the back seems to point to a custom of beating the victim to be slain, and if, as seems probable, the beating of the Roman scapegoat Mamurius Vetulus was inflicted by the Salii, an interesting parallel is suggested by the padded backs of the kalogheroi and the long wands carried by the katsiveloi.

But such a custom in Thrace suggests also a survival of the worship of Dionysus, upon which recent researches have thrown so much light. The circumstances are favourable to such a survival in a Greek community occupying the old city of the kings of Thrace, and surrounded and isolated by later elements of population, Bulgarian and Circassian.

The first striking point is the old nurse Babo carrying the child in a $\lambda i \kappa \nu$. The survival of this word in the sense of a cradle, coupled with the strange use of a basket for the Babo's child, can hardly, under the circumstances, be anything else than a direct descendant of the classical use of the liknon in the worship of Dionysus. Then, as now, a basket was not a usual form of cradle, and when it was used it was with the idea of magically bringing good

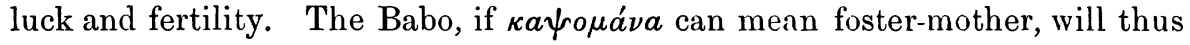
represent the nursing nymphs, and in any case the tradition that the child is bastard and his epithet $\dot{\epsilon} \phi \tau a \mu \eta \nu i \tau \iota \kappa o$, a seven-months child, are appropriate to the premature birth of Dionysus, the love child of Semele, son of a mysterious father. The complaint of the Babo, that the child is growing too big for his cradle and wants a wife, suggests his identification with the leading kalogheros,

15 Fiedler, Reise durch alle Theile des Koenigreiches Griechenland, 1841, ii. p. 83.
16 Golden Bough, i. p. 98 .

17 Ibid. i. p. 36. 
who is at that point of the play just about to take one of the koritsic as his wife. A marriage is known to have been a part of the cult in Crete and at Athens, where it took place in the boukoleion, a place connected with the solemn ploughing ceremonies of Athenian religion. ${ }^{18}$ That a phallophoria formed part of the worship of Dionysus has been clearly shown. ${ }^{19}$ The death and the mimetic flaying and resurrection follow in due order. But what is to be said of the 7iatsiveloi, the gipsy smiths who make the plough, and of the almost indistinguishable actor who kills the Dionysus? The classical Dionysus was killed by his worshippers and attendants the Titans, who also were smiths, so it may be hazarded that the second actor and the katsiveloi represent characters originally the same, and these simply the worshippers of the god. The identification of the Satyrs with the Satrae of Thrace, and of the Titans with the worshippers, who first killed and then lamented the god, shows that the second actor and the katsiveloi have this common origin and are to be compared with the Kouretes and Salii. The significance of their rods in the light of the beating of the Roman scapegoat by the Salii has been alluded to above, and whilst Vizyenos asserts that the lialogheroi beat one another, it may be suspected that originally a beating was inflicted upon the first kalogheros by the second and the rod-bearing katsiveloi. In later times, when the gipsies came to be regarded as the typical smiths, the making of the ploughshare, the special task of the god's typical devotees, was assigned to them, whilst the part of the slayer has by an odd confusion been given to a duplicate of Dionysus, whose later origin is indicated by the parallels at Kosti and Skyros, where it is possible that once the Frank killed the masked actor. ${ }^{20}$ The obscene gestures of the gipsies seem likely to be a survival of the marriage of the principal character. The use of such acts as a fertility charm, whether the connexion with the straw-heaps be accidental or not, is noticed by Dr. Frazer. ${ }^{21}$

The disguise as an animal and, although all sorts of skins are used, presumably from his drawing the plough, as a bull, fits with the tauromorphic form of the Thracian Dionysus. The death and flaying of the kalogheros thus appears as the descendant of the practice of killing and eating the bull-god of vegetation, possibly once as a human victim.

The giving of wine by the king at Kostí is an act worthy of the wine god, the more remarkable as such masqueraders are generally more apt to take than to give. It reminds us of the miracle of St. George of Skyros, who on his festival multiplies the wine poured into a jar sunk in the earth in front of his church. ${ }^{22}$

18 The Boukoleion and the Bouzygion, the field of the sacred ox-ploughing, were in close connexion. Harrison and Verrall, Mythology and Monuments, p. 166.

19 J. E. Harrison, 'Mystica vannus Iacchi,' J.H.S. xxiii. p. 322 .

20 It is possible that the second kalogheros is the divine king of the coming year, who kills his predecessor, just as at Nemi each king was killed by his successor. But the single actors in the parallel Greek observances make the view followed in the text, that the second kxlogheros is later, more likely.

21 Golden Bough, ii. p. $205 \mathrm{sqq}$.

${ }^{22}$ B.S.A. xi. p. 75. 
Common to all these festivals is the use of bells, whose prophylactic nature has been shown by Mr. A. B. Cook. ${ }^{23}$ Especially to the point here are the clashing shields of the Salii, compared by Dionysius (II. 70) with the Curetes, of which Warde Fowler says: "The old Latins believed that the spirit which was beginning to make the crops grow must at this time (March 1st) be protected from hostile demons in order that he might be free to perform his friendly functions for the community.' ${ }^{24}$

In view of the resemblance of these festivals to one another, the history of the populations of Skyros and of this part of Thrace is of importance. The subject is obscure and I am indebted to Dr. Clon Stephanos for a reference to a contemporary authority ${ }^{25}$ from which we learn that in 1645 the Venetian Foscolo transported the inhabitants of Skyros to Corfou. Thus it appears that the present inhabitants have hardly been there more than two hundred years.

If the island was thus depopulated, there are some indications whence the new inhabitants came. A study of the modern dialect of the town of Sarínda Ekklisíes, about nine hours north-west of Viza, has recently been published, ${ }^{26}$ in which the writer points out that it varies from the norm of the Northern Greek dialects as laid down by Hatzidhakis, ${ }^{27}$ that in unaccented syllables $e$ and $o$ change to $i$ and $o u$, whilst $i$ and $o u$ disappear, in only being subject to the latter change. I noted the same peculiarity in the almost exactly similar dialect of Viza. From this, and from certain points of resemblance to southern dialects, the writer suggests that the population of this part of Thrace has come from some southern region since the fifteenth century, Hatzidhakis assigning the beginning of the differentiation of the Northern and Southern dialects to that period. But the resemblances on which he relies are very slight, and the point that seems really remarkable is that as regards this vowel-weakening, the dialect of Skyros stands in exactly the same position as these Thracian idioms. ${ }^{28}$ Before drawing any certain conclusions, it would be necessary to have a more extended knowledge of the modern dialects than the material at present available admits. But it seems at least a plausible view that the vacancy created in Skyros by Foscolo was filled by emigrants from Thrace, bringing with them this festival.

It may also be noted that the native embroidery of Skyros has nothing in common with that of the southern islands, whilst it is almost indistinguishable from that of the northern regions to which the dealers give the general

\footnotetext{
23 'The Gong at Dodona,' J.H.S. xxii. p. 5 .

24 Raman Festivals, p. 41.

25 The reference is to a poem on Cretan

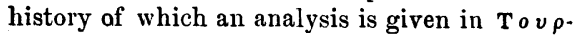

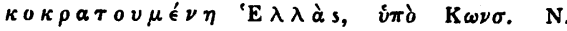

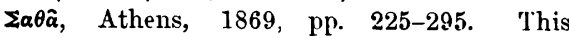
deportation of the Skyrians is narrated on p. 265 .
}

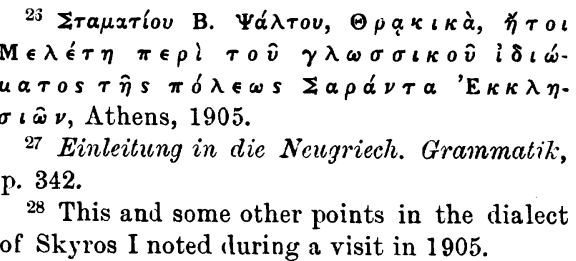

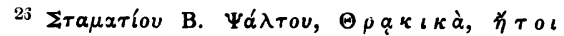

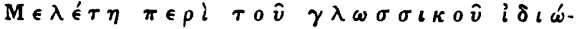

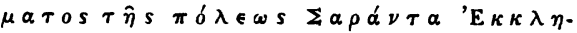
ens, 1905 . 342. of Skyros I noted dluring a visit in 1905 
name of Jannina. It thus appears that whatever evidence we have tends to connect Skyros with the north, and thus to bind together this closely allied group of Carnival observances.

R. M. Dawkins.

I owe to Mr. Bosanquet the following note on a custom which he witnessed at Tripolitza in the Peloponnese. He writes that it is an old custom in this place for the boys to run round the town at sunset on the last day of February, clashing bells, and with especial vigour round any lame person they may meet. He saw the troop of boys brandishing bells, or with bells round their waists, headed by a lame boy, who carried no bell, but swung himself along at a great pace with the help of a stick. Asked what

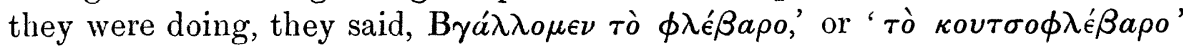

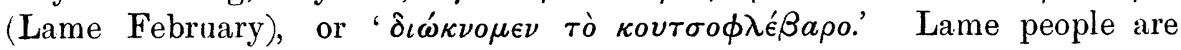
treated as personifications of the lame month. Mr. Bosanquet suggests that contact with some such custom may have helped in Skyros to obliterate the other features of the Carnival play, and to generalise and emphasize the bellringing element.

\section{Note in addition to Note 7,p. 196.}

With the Babo compare the ancient Baubo (Clem. Alex. Protrept. ii. 20). With the derivation of the meaning 'mother of an illegitimate child' from ' maiden-mother' compare the Lacedaemonian parthenioi.

In Zagori in Epeirus $\kappa a \psi o-$ is used as a prefix to the names of unlucky

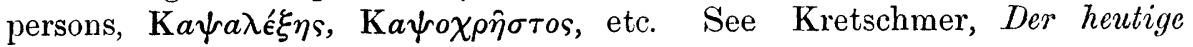
Lesbische Dialelt, p. 387.

R. M. D. 